Jurnal Konstruksi Hukum | ISSN: XXXX | E-ISSN: XXXX Vol. 1, No. 1, September 2020 Hal. 91-97| Available online at https://www.ejournal.warmadewa.ac.id/index.php/jukonhum DOI: https://doi.org/10.22225/jkh.1.1.2136.91-97

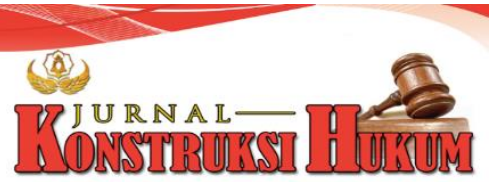

\title{
EFEKTIFITAS LEMBAGA BIPARTIT DALAM MENYELESAIKAN SENGKETA HUBUNGAN INDUSTRIAL PADA PERUSAHAAN PT. NEW KUTA GOLF AND OCEAN VIEW
}

\author{
Dynna Madina Karuniawan, I Nyoman Putu Budiartha, I Putu Gede Seputra \\ Universitas Warmadewa, Denpasar-Bali, Indonesia
}

\begin{abstract}
Abstrak
Tuntutan industrialisasi yang semakin penting dilakukan untuk kemajuan suatu negara. Hal ini membawa konsekuensi pada pengusaha untuk sedapat mungkin menggunakan sistem kerja yang efektif. Namun adanya perselisihan hubungan industrial antara buruh dan pengusaha seringkali menjadi masalah. Oleh karena itu, diperlukan seperangkat hukum yang dapat menjadi wadah tersendiri untuk menangani masalah-masalah perselisihan dalam perusahaan, dalam hal ini adalah LKS Bipartit. Permasalahan yang diangkat adalah bagaimana efektifitas Lembaga Bipartit dan hal-hal apa saja yang menghambat dalam menyelesaikan permasalahan ketenagakerjaan di PT. New Kuta Golf and Ocean View. Metode penelitian yang digunakan adalah metode penelitian hukum empiris melalui pendekatan sosiologi hukum. Hasil penelitian ini menunjukkan bahwa efektivitas LKS Bipartit bagi perusahaan sudah sesuai tugas dan fungsinya, dimana LKS Bipartit berperan aktif sebagai media musyawarah yang positif untuk digunakan sebagai tempat komunikasi dan konsultasi terkait kebijakan-kebijakan baru dari perusahaan serta tempat mengungkapkan aspirasi para pihak pekerja untuk tercapainya kebijakan yang tidak merugikan salah satu pihak. Selain itu, faktor penghambat yang ditemukan dalam menyelesaikan permasalahan ketenagakerjaan di PT. New Kuta Golf and Ocean View adalah lemahnya pola pikir pihak pekerja terhadap pentingnya LKS Bipartit, keterbatasan informasi, kurangnya SDM yang kompeten terhadap pemahaman prosedur LKS Bipartit yang sesuai Undang-Undang.
\end{abstract}

Kata Kunci: Hubungan industrial; Lembaga Bipartit; PT. New Kuta golf and ocean view

\begin{abstract}
The demand for industrialization is increasingly important for the progress of a country. This case has consequences for employers to use an effective work system wherever possible. However, industrial relations disputes between workers and employers often become a problem. Therefore, it is necessary to have a set of laws that can be a separate forum for dealing with disputes in the company, in this case, the Bipartite institution. The issues raised were how effective the Bipartite Institution was and what the obstacles in resolving labor problems at PT. New Kuta Golf and Ocean View were. The research method used is an empirical legal research method through the sociology of law approach. The results of this study indicate that the effectiveness of the Bipartite institution for the company is in accordance with its duties and functions, where the Bipartite institution played an active role as a positive deliberation medium to be used as a place of communication and consultation regarding new company policies as well as a place to express the aspirations of workers to achieve policy which does not harm either party. In addition, the inhibiting factors found in solving employment problems at PT. New Kuta Golf and Ocean View were the weak mindsets of workers regarding the importance of Bipartite institutions, limited information, lack of competent human resources to understand the procedures for Bipartite institutions in accordance with the law.
\end{abstract}

Keywords: Industrial relations; Bipartite institution; PT. New Kuta golf and ocean view

\section{PENDAHULUAN}

Proses industrialisasi yang semakin meluas pada negara berkembang seperti Indonesia membawa konsekuensi pada ketertarikan pengusaha untuk sedapat mungkin menggunakan sistem kerja yang efektif agar mendukung dan memaksimalkan operasional suatu perusahaan. Hubungan industrial antara buruh dan pengusaha sebagaimanapun harmonisnya, perselisihan perburuhan tidak mudah untuk dihindari (Sudiarawan, 2017). Oleh karena itu, seperangkat hukum yang mengatur mekanisme penyelesaian perselisihan perburuhan akan selalu menempati posisi strategis dalam sistem perburuhan suatu perusahaan. 
Menurut UU Tentang Penyelesaian Perselisihan Hubungan Industrial pada Pasal 1 angka 3 UU No. 2 Tahun 2004 dikatakan bahwa "Perselisihan kepentingan adalah perselisihan yang timbul dalam hubungan kerja karena tidak adanya kesesuaian pendapat mengenai pembuatan, dan atau perubahan syarat-syarat kerja yang ditetapkan dalam perjanjian kerja, atau peraturan perusahaan, atau perjanjian kerja bersama." Perselisihan hak adalah perselisihan yang timbul karena tidak dipenuhinya hak akibat dari perbedaan pelaksanaan atau penafsiran terhadap Perundang-Undangan, PK, PP atau PKB. Perselisihan-perselisihan hubungan industrial tersebut oleh para pihak haruslah diselesaikan agar tidak terjadinya pelanggaran atas hak orang lain. Menurut UU Tentang Penyelesaian Perselisihan Hubungan Industrial pada No. 2 Tahun 2004 penyelesaian dapat dilakukan melalui lembaga -lembaga berikut, Perundingan Bipartit, Mediasi Hubungan Industrial, Konsiliasi Hubungan Industrial, Arbritrase Hubungan Industrial dan Pengadilan Hubungan Industrial.

Perspektif hukum dalam perburuhan suatu hubungan industrial memerlukan proses komunikasi, konsultasi, dan musyawarah mengenai hal-hal yang terkait dengan berbagai aspek (Dahlia \& Jumiati, 2011; Zulkarnaen \& Utami, 2016). Hubungan industrial yang harmonis dapat menjadi modal penting di dalam persaingan bebas. Hubungan industrial harmonis akan mampu mendorong transparansi yang dapat meningkatkan saling pengertian antara pekerja dan perusahaan. Namun, perselisihan sangat rentan terjadi dalam hubungan antara buruh dan pengusaha karena fokus utama dari hubungan kerja yang dibangun perusahaan adalah suatu hubungan kerja yang berorientasi pada target dan keuntungan sehingga berimplikasi pada tekanan kerja tinggi yang dialami oleh pihak pekerja. Perselisihan hubungan industrial dalam bingkai hukum perburuhan didefinisikan sebagai perbedaan pendapat yang mengakibatkan pertentangan antara pengusaha atau gabungan pengusaha dengan buruh atau serikat buruh karena adanya berbagai perselisihan, seperti perselisihan hak, kepentingan, pemutusan hubungan kerja dan perselisihan antar serikat pekerja dalam suatu perusahaan (PN, 2018; Santoso, 2019).

Penyelesaian perselisihan perburuhan pada awalnya dilaksanakan melalui perantara negara, yaitu melalui panitia penyelesaian perselisihan daerah dan panitia penyelesaian perselisihan pusat (Adi, 2004). Namun upaya ini dianggap tidak efektif, sehingga digunakan Undang- Undang Nomor 2 Tahun 2004 tentang Penyelesaian Perselisihan Hubungan Industrial (UU PPHI) yang dirasa dapat menyelesaikan perselisihan secara cepat, tepat, adil, dan murah.

UU PPHI hadir dengan merombak total sistem penyelesaian perselisihan perburuhan yang telah ada sebelumnya. UU ini mengakomodir sistem penyelesaian sengketa tiga tingkat (Bipartit, Tripartit, dan Pengadilan Hubungan Industrial) yang hingga kini masih digunakan dalam menyelesaikan permasalahan-permasalahan terkait hubungan industrial dalam sistem hukum Ketenagakerjaan Indonesia agar konfrontasi antara pekerja dan pengusaha dapat dihindari atau dicegah lebih dini. Saling pengertian mengenai kepentingan bersama dapat dikembangkan sehingga tujuan serta aspek terpenting dalam menciptakan ketenagakerjaan dan kelangsungan usaha dapat diwujudkan. Di sisi lain masalah ketenagakerjaan masih banyak terjadi.

Gangguan kepentingan atau konflik haruslah dicegah sehingga tidak akan menganggu keseimbangan dalam suatu lingkungan kerja seperti pada perusahaan PT. New Kuta Golf and Ocean View. Permasalahan-permasalahan yang dapat terjadi diharapkan mampu ditekan agar senantiasa tercipta suasana kerja yang tertib, damai, dan aman, sehingga visi misi perusahaan dapat tercapai.

Berdasarkan latar belakang di atas, penelitian ini dilakukan dengan tujuan mendeskripsikan bagaimana efektifitas Lembaga Bipartit dan hal-hal apa saja yang menghambat dalam menyelesaikan permasalahan ketenagakerjaan di PT. New Kuta Golf and Ocean View.

\section{METODE PENELITIAN}

Penelitian ini didesain dengan menggunakan metode penelitian hukum empiris. Metode ini digunakan berdasarkan tujuan penelitian ini, yaitu mengungkap fakta-fakta yang ada di lapangan. Pendekatan yang digunakan adalah pendekatan sosiologi hukum. Sumber data penelitian ini adalah manager PT. New Kuta Golf and Ocean View dan Undang-Undang Ketenagakerjaan. Data dikumpulkan dengan metode interview dan dokumentasi. Data yang sudah terkumpul dianalisis menggunakan metode kualitatif dan disajikan secara deskriptif. 


\section{HASIL DAN PEMBAHASAN}

\section{Efektifitas Lembaga Bipartit dalam Menyelesaikan Permasalahan Ketenagakerjaan di Perusahaan PT. New Kuta Golf and Ocean View}

Lembaga Kerja Sama Bipartit adalah lembaga yang ada dalam perusahaan yang berfungsi sebagai forum kemunikasi, konsultasi, dan musyawarah untuk mufakat dalam menyelesaikan masalah ketenagakerjaan. Keanggotaan LKS Bipartit terdiri dari pihak pekerja dan pihak pengusaha (Karuniawan, 2004). LKS Bipartit ini juga ada pada perusahaan PT. New Kuta Golf and Ocean View. Makna lembaga Kerja Sama Bipartit berdasarkan Pasal 1 angka 18 Undang-undang Ketenagakerjaan jo. Pasal 1 angka 1 Permenakertrans No. PER.32/MEN/XII/2008, didefinisikan sebagai sebuah forum komunikasi dan konsultasi mengenai hal-hal yang berkaitan dengan hubungan industrial di suatu perusahaan. Anggotanya meliputi pengusaha dan serikat pekerja atau serikat buruh (SP/SB) yang sudah tercatat dalam instansi yang bertanggung jawab dibidang ketenagakerjaan atau unsur pekerja atau buruh.

LKS Bipartit pada perusahaan PT. New Kuta Golf and Ocean View sangat diterima dan bermanfaat bagi perusahaan karena dapat berperan aktif sebagai lembaga permusyawarahan kerjasama antara pengusaha dan pekerja secara kekeluargaan. LKS Bipartit berhasil terlaksana sebagai forum komunikasi, konsultasi dan musyawarah yang berimplikasi terhadap kewenangan dan produk perusahaan. Hal ini diharapkan dapat menjadi pendorong bagi pengusaha-pengusaha lainnya untuk membentuk LKS Bipartit pada perusahaan yang dipimpinnya karena lembaga ini dapat menjembatani dan sekaligus mendeteksi timbulnya permasalahan ketenagakerjaan secara dini. LKS Bipartit pada perusahaan PT. New Kuta Golf and Ocean View dapat menciptakan suasana hubungan kerja yang harmonis dan transparan bagi perusahaan.

LKS Bipartit berfungsi sebagai forum komunikasi, konsultasi, dan musyawarah dalam memecahkan dan menyelesaikan permasalahan ketenagakerkaan di perusahaan dalam rangka menciptakan ketenangan industrial (Industrial Peace) dan keharmonisan industrial (Industrial Harmony) (Marbun, Ginting, Tarigan, \& Agusmidah, 2017). Berdasarkan P asal 106 ayat 2 UU Ketenagakerjaan, tugas dan fungsi LKS Bipartit yaitu sebagai forum komunikasi dan konsultasi mengenai hal-hal ketenagakerjaan di perusahaan. Fungsi tersebut bertujuan dalam upaya pengembangan hubungan industrial untuk kemajuan perusahaan itu sendiri termasuk di dalamnya juga kesejahteraan dari pihak pekerja. Jadi, fungsi LKS Bipartit adalah sebagai forum untuk membahas kendala-kendala dalam hubungan industrial di perusahaan guna meningkatkan produktivitas kerja dan kesejahteraan buruh yang menjamin kelangsungan usaha dan menciptakan ketenangan kerja. LKS Bipartit tersebut berlaku untuk semua hal mengenai ketenagakerjaan sehingga diharapkan dapat mencegah timbulnya permasalahan Hubungan Industrial.

Tugas LKS Bipartit pada perusahaan PT. New Kuta Golf and Ocean View di antaranya mengadakan pertemua secara periodik atau dalam waktu-waktu tertentu apabila diperlukan, melakukan komunikasi dan musyawarah untuk mendiskusikan adanya permasalahan kerja yang sedang terjadi dan meminimalisir kesalahan-kesalahan yang akan terjadi, serta memberikan kesempatan kepada serikat pekerja untuk memberikan saran dan masukan atas kebijakan yang dibuat oleh perusahaan. Hal ini menunjukkan bahwa perusahaan telah melaksanakan program LKS Bipartit sesuai dengan yang dimaksudkan dalam Pasal 106 ayat 2 UU Ketenagakerjaan tentang Tugas dan Fungsi LKS Bipartit. Dengan demikian, LKS Bipartit dapat mendeteksi dan menekan adanya permasalahan Hubungan Industrial yang mungkin terjadi sehingga permasalahan-permasalahan yang muncul tidak sampai meningkat menjadi perselisihan, unjuk rasa, atau pemogokkan.

LKS Bipartit pada perusahaan PT. New Kuta Golf and Ocean View memberikan media untuk bertukar pikiran dan menjadi sarana musyawarah yang lebih efektif, efisien dan transparan antara perusahaan dengan pekerja. Selain itu, lembaga ini juga membuat masalah dapat dicegah dan diminimalisir serta kinerja dapat dilakukan sesuai arahan sehingga menghasilkan kerja yang optimal dan efektif. Dengan adanya pertemuan-pertemuan forum LKS Bipartit, beberapa pekerjaan jadi lebih mudah dalam pelaksanaan kerja karena adanya pengarahan lebih awal dari pihak perusahaan. Oleh karena itu, LKS Bipartit dirasa memberikan dampak positif untuk kemudahan dalam melakukan usaha kerja. Peran LKS Bipartit menjadi sangat efektif untuk kemajuan perusahaan apabila SDM yang ahli di bidangnya dari pihak pengusaha dapat memediasi seluruh permasalahan-permasalahan yang dipaparkan oleh pihak pekerja. Jadi, adanya dorongan, motivasi, dan keterlibatan dari pemerintah dalam hal ini masih diharapkan. 


\section{Faktor-Faktor yang Menghambat dalam Menyelesaikan Permasalahan Ketenagakerjaan pada Perusahaan PT. New Kuta Golf and Ocean View}

Konflik antara pekerja dan pengusaha dalam suatu hubungan kerja pada suatu perusahaan merupakan bagian yang timbul secara alami dan tidak dapat dihindarkan lagi. Pada hakikatnya masalah perselisihan atau konflik merupakan interaksi pertentangan antara dua pihak atau lebih karena pihakpihak tersebut memiliki kepentingan yang berbeda. Dari pihak pekerja yang menginginkan hasil sebanyak-banyaknya dari pekerjaanya dan pihak pengusaha ingin memperoleh keuntungan yang sebesar-besarnya dari sumber daya yang sama (Sudiarawan, 2017).

\section{Jenis Masalah yang Terjadi di Perusahaan PT. New Kuta Golf and Ocean View}
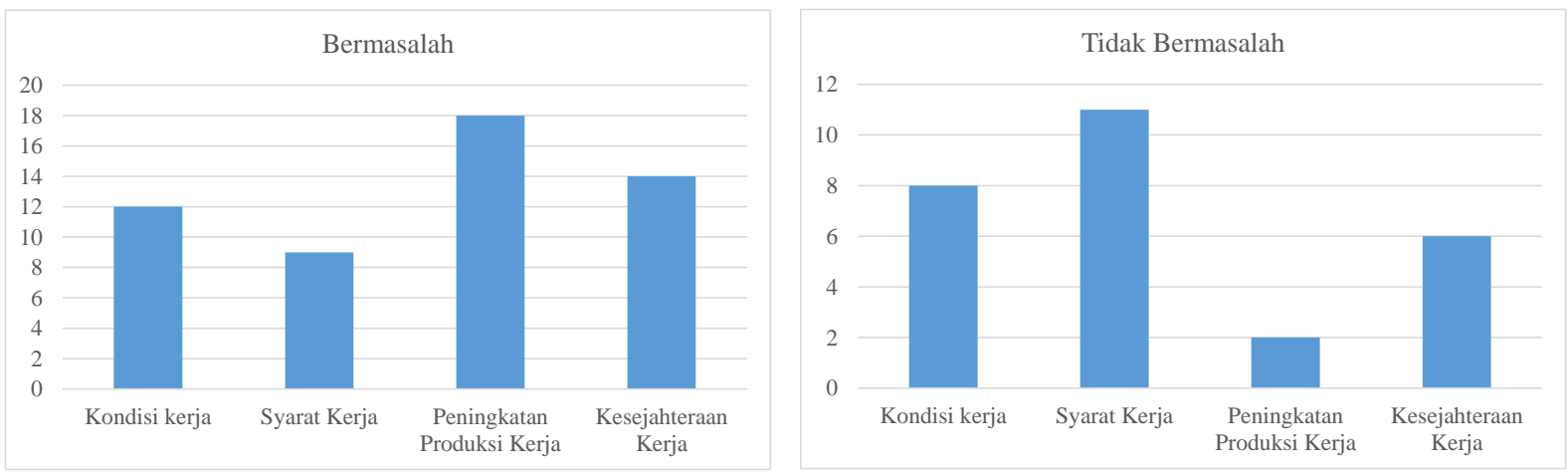

Jenis perselisihan yang terjadi pada perusahaan PT. New Kuta Golf and Ocean View berdasarkan grafik antara lain:

1. Kondisi kerja, meliputi permasalahan perlindungan teknis yang bertujuan agar pekerja terhindar dari bahaya yang dapat ditimbulkan oleh alat-alat atau bahan-bahan yang digunakan pada saat bekerja. Perselisihan dalam kondisi kerja memiliki masalah yang sedikit dan jarang terjadi karena secara efektif dilaksanakan melalui wadah panitia pembina keselamatan dan kesehatan kerja diperusahaan.

2. Syarat-syarat kerja, adalah segala petunjuk atau aturan yang harus dipatuhi dan dilakukan bersama oleh pekerja maupun pengusaha. Syarat kerja meliputi aturan seragam kerja, waktu kerja, waktu istirahat, waktu lembur, waktu libur dan waktu cuti. Perselisihan dalam Syarat kerja memiliki masalah yang paling sedikit dan tidak banyak dipermasalahkan kedua pihak, karena baik seragam maupun kelengkapan lain yang ditentukan dala $\mathrm{m}$ aturan kerja perusahaan, sudah diakomodasi oleh perusahaan.

3. Peningkatan produktifitas kerja, merupakan salah satu perhatian utama perusahaan. Guna untuk mendapatkan keuntungan yang maksimal, pihak pengusaha akan selalu mengoptimalkan sumber daya manusia dalam hal ini adalah pihak pekerja untuk kerja semaksimal mungkin. Permasalahan banyak terjadi antara pihak pekerja dan pengusaha, diantaranya tuntutan yang tinggi diminta oleh pihak pengusaha kepada pihak pekerja sehingga memberikan tekanan untuk selalu bekerja seproduktif dan seefektif mungkin. Pihak pengusaha sendiri tentunya ikut andil dalam upaya peningkatan produksi kerja untuk meningkatkan SDM yang ada, yaitu dengan memberikan dorongan berupa pemberian jenjang karir, jaminan atau kepastian kerja serta pendidikan dan pelatihan.

4. Kesejahteraan kerja, merupakan salah satu kepentingan pekerja yang harus dipenuhi berdasarkan hasil pekerjaan yang telah dicapai. Permasalahan dalam kesejahteraan kerja meliputi upah yaitu upah pokok dan tunjangan tetap, dan bukan upah yaitu fasilitas seperti fasilitas kendaraan, pemberian makan cuma-cuma, sarana ibadah dan lain- lain, bonus, serta tunjangan hari raya. Permasalahan dalam kesejahteraan kerja termasuk salah satu yang sering terjadi, terutama akibat dari luar perusahaan yang bersifat menyeluruh seperti adanya inflasi nilai mata uang dan kenaikan harga BBM di Indonesia. Bentuk permasalahan ini paling sering dikeluhkan oleh pihak pekerja. Akan tetapi, dampak yang disebabkan juga berimplikasi pada menurunnya keuntungan perusahaan. Selain itu, masalah besar yang baru muncul yaitu adanya pandemi COVID-19 memberikan dampak yang sangat buruk terhadap perusahaan. Pandemi COVID-19 menyebabkan 
jumlah pengunjung atau tamu yang menurun drastis dari target sehingga pihak pengusahan dan pekerja harus berusha lebih keras untuk mempertahankan perusahaan.

Sebagai penyelesaian masalah, para pihak melakukan penyelesaian masalahan pada tingkat perusahaan yaitu melalui LKS Bipartit sebagai forum komunikasi, konsultasi dan musyawarah. Sebagian besar masalah yang ada diselesaikan melalui LKS Bipartit. Masalah-masalah tersebut dibuka dan diselesaikan oleh LKS Bipartit secara musyawarah untuk mendapatkan penyelesaian secara kekeluargaan.

Penyelesaian melalui LKS Bipartit dilakukan dengan cara mediasi secara periodik antara pihak pengusaha dengan pihak pekerja yang memiliki keluh kesah. Mediasi dilakukan melalui Departemen HR. Pihak pengusaha memberikan arahan dan penyelesaian dengan asas kekeluargaan untuk mencapai persetujuan penyelesaian masalah. Selanjutnya, dari hasil mediasi dibuatkan rekomendasi sebagai bahan pertimbangan dalam pembuatan MOU atau Kesepakatan Kerja Bersama (KKB). Hasil akhir yang ingin dicapai kedua pihak adalah ketenangan kerja dan kelangsungan berusaha untuk kebaikan kedua belah pihak. Penyelesaian perselisihan melalui Bipartit diatur dalam ketentuan Pasal 3 sampai dengan Pasal 7 UU No. 2 Tahun 2004. Penyelesaian ini dilakukan melalui negosiasi dan musyawarah demi upaya penyelesaian sengketa oleh para pihak dengan tanpa melibatkan pihak lain dengan tujuan mencari kesepakatan bersama atas dasar kerjasama yang harmonis dan kreatif (Budiartha, 2016).

Permasalahan perusahaan akibat adanya pandemi COVID-19 mengharuskan perusahan PT. New Kuta Golf and Ocean View mengambil keputusan untuk memberikan surat Pemutusan Hubungan Kerja kepada beberapa pekerja. Tentunya hal ini tidak diharapkan terjadi baik oleh pihak pekerja maupun pihak pengusaha. Selain merugikan pihak pekerja, tentunya perusahan sendiri akan kehilangan SDA yang sudah berperan dalam kemajuan perusahaan selama ini. Langkah penyelesaian melalui pemutusan hubungan kerja yang diambil sepihak oleh pihak pengusaha ini dilakukan untuk mempertahankan perusahaan dari kondisi krisi yang bersifat global akibat pandemi COVID-19. Lalu Husni dalam bukunya menyatakan bahwa "Pemutusan Hubungan Kerja adalah pengakhiran hubungan kerja antara pengusaha dan pekerja karena berbagai sebab". Menurut Pasal 1 angka 25 UU No. 13 Tahun 2003, yang dimaksud dengan pemutusan hubungan kerja adalah perselisihan yang timbul karena tidak adanya kesesuaian pendapat mengenai pengakhiran hubungan kerja yang dilakukan oleh salah satu pihak (Husni, 2017).

Faktor-faktor penghambat LKS Bipartit untuk melaksanakan tugas dan fungsinya yaitu:

a. Faktor penghambat dari pekerja. Adanya hasil pertemuan LKS Bipartit yang tidak dapat segera direalisasikan akan menimbulkan rasa tidak percaya lagi terhadap keberadaan LKS Bipartit; rendahnya kualitas personil yang dapat menangani secara profesional keberadaan LKS Bipartit; dan lemahnya pemahaman mengenai peran, fungsi dan manfaat LKS Bipartit bagi pekerja menyebabkan adanya LKS Bipartit kurang membantu. Hal ini kemudian acuh tak acuh terhadap pengaturan-pengaturan strategis dalam hukum ketenagakerjaan yang potensial dapat digunakan sebagai sarana perlindungan bagi pihak pekerja dalam memperjuangkan hak-hak mereka.

b. Faktor penghambat dari pengusaha. Adanya pertemuan yang dilakukan secara periodik oleh LKS Bipartit dalam lingkungan perusahaan diasumsikan akan mengurangi jam kerja dan menambah biaya; dalam melaksanakan tugas dan fungsi LKS Bipartit, ketersediaan sumber daya teknis bidang hubungan industrial yang melaksanakan fungsi pembinaan termasuk penyuluhan atau sosialisasi masih terbatas secara kualitas dan kuantitas; dan masih minimnya pemahaman akan prosedur terkait penyelesaian permasalahan Hubungan industrial melalui LKS Bipartit yang sesuai dengan peraturan Perundang-Undangan untuk perusahaaan sehingga menimbulkan kesulitan dalam mengambil keputusan.

c. Faktor penghambat dari perspektif Pemerintah. Ketersediaan sumber daya manusia khusus pegawai teknis bidang hubungan industrial yang melaksanakan fungsi pembinaan termasuk penyuluhan dan sosialisasi masih terbatas secara kualitas dan kuantitas. Hal ini berpengaruh pada proses pembinaan yang semakin sulit mengingat jumlah yang tidak seimbang dengan banyaknya jumlah perusahaan yang memenuhi syarat pembentukan LKS Bipartit; diperlukan sumber daya manusia yang memiliki kompetensi kuat dengan jumlah yang memadai guna memaksimalkan proses pembinaan dalam kaitannya dengan penerapan LKS Bipartit.

Agar LKS Bipartit dapat berperan dan berfungsi dengan semestinya, baik dari pihak pemerintah maupun pihak perusahaan seharusnya memiliki kesadaran serta komitmen dalam menggalakkan dan 
menjalankan peran LKS Bipartit sebagai media konsultatif, musyawarah serta pencegahan masalah. Mengaktifkan LKS Bipartit sebagai lembaga berinovasi untuk kerja sama yang saling menguntungkan antara pengusaha dengan pihak pekerja. Pengusaha seharusnya siap untuk berbagi informasi, keterbukaan dan tanggung jawab dalam mempromosikan LKS Bipartit di perusahaan serta menyadari bahwa peran dan fungsi LKS Bipartit sangat penting dan diperlukan.

\section{SIMPULAN DAN SARAN}

\section{Simpulan}

Berdasarkan hasil penelitian yang telah diuraikan di atas, ada beberapa simpulan yang dapat dibuat, yaitu: pertama, efektivitas LKS Bipartit bagi perusahaan sudah sesuai tugas dan fungsinya, dimana LKS Bipartit berperan aktif sebagai media musyawarah yang positif untuk digunakan sebagai tempat komunikasi dan konsultasi terkait kebijakan-kebijakan baru dari perusahaan serta tempat mengungkapkan aspirasi para pihak pekerja untuk tercapainya kebijakan yang tidak merugikan salah satu pihak. Selain itu LKS Bipartit juga menjadi alat preventif untuk menciptakan lingkungan kerja yang harmonis, terarah dan sesuai visi misi perusahaan PT New Kuta Golf and Ocean View. Kedua, faktor-faktor penghambat terhdap penerapakan LKS Bipartit pada perusahaan PT New Kuta Golf and Ocean View yaitu lemahnya pola pikir dan minimya pemahaman pihak pekerja terhadap pentingnya LKS Bipartit. Selain itu juga terbatasnya SDM yang kompeten mengenai prosedur dan tatacara penyelesaian masalah melaui LKS Bipartit yang sesuai dengan Peraturan Perundang-undangan serta Peran pemerintah dalam menggalakkan pemahaman mengenai pentingnya LKS Biparti bagi perusahaan yang juga masih minim.

\section{Saran}

Selain simpulan, ada juga beberapa saran yang perlu disampaikan kepada beberapa pihak berdasarkan hasil penelitian ini, yaitu: bagi pekerja, ikut berperan aktif dalam LKS Bipartit, mengikuti arahan yang disosialisasikan baik oleh perusahaan maupun dari pemerintah serta dapat memanfaatkan LKS Bipartit sebagai sarana bertukar pikiran untuk menciptakan lingkungan kerja yang harmonis, mengikuti segala bentuk sosialisasi, dan memahami informasi yang disampaikan oleh perusahaan dan pemerintah dalam bentuk apapun, seperti papan iklan, seminar dan sebagainya; bagi perusahaan, perlu pengoptimalan LKS Bipartit sebagai sarana penyelesaian segala bentuk permasalahan yang ada di perusahaan. Bentuk pengoptimalan dapat berupa melibatkan LKS Bipartit dalam event-event perusahaan. Selain itu Penyuluhan lebih intensif oleh perusahaan terkait penerapan LKS Bipartit sangat diperlukan, terutama sharing informasi terbaru mengenai prosedur pelaksanaan tugas dan fungsi serta manfaat LKS Bipartit untuk perkembangan perusahaan khususnya pada perusahaan PT New Kuta Golf and Ocean View; dan bagi pemerintah, Kementerian ketenagakerjaan khususnya Dinas Tenaga Kerja baik di tingkat kota atau kabupaten dan provinsi harus mengubah dalam melakukan pendekatan kepada pelaku proses produksi barang dan jasa yang selama ini dilakukan dengan pendekatan sesi hukum saja, tetapi perlu didukung dengan penyuluhan yang intensif dan komprehensif dengan pemasangan iklan layanan masyarakat di televisi karena dapat menjangkau seluruh lapisan masyarakat sehingga dapat membentuk opini positif di masyarakat dan menghilangkan presepsi negatif LKS Bipartit di perusahaan maupun masyarakat. Selain itu penyuluhan yang lain juga perlu di intensifkan seperti pemasangan iklan Billbord di jalan-jalan strategis, Bimtek, Seminar dan lain-lain. Dengan demikian semakin banyak pengusaha dan pekerja atau buruh atau serikat pe kerja atau serikat buruh yang mengerti dan sadar arti pentingnya LKS Bipartit di perusahaan.

\section{DAFTAR PUSTAKA}

Adi, M. K. (2004). Implikasi Yuridis Penyelesaian Perselisihan Hubungan Industrial melalui Pengadilan Hubungan Industrial. Jurnal Hukum, 11(27), 62-71.

Budiartha, I. N. P. (2016). Hukum Outsourcing Konsep Alih Daya Bentuk perlindungan dan Kepastian Hukum. Malang: Setara Press.

Dahlia, \& Jumiati, A. (2011). Penyelesaian Perselisihan Hubungan Industrial Berdasarkan UU Nomor 2 Tahun 2004. Wacana Hukum, IX(2).

Husni, L. (2017). Penyelesaian Hubungan Industrial melalui Pengadilan \& di Luar Pengadilan. Jakarta: PT. Raja Grafindo Persada. 
Karuniawan, H. (2004). Peranan Lembaga Bipartit dalam Menyelesaikan Masalah Ketenagakerjaan pada Perusahaan Perhotelan di Kawasan Wisata Nusa Dua - Bali (Universitas Gadjah Mada).

Marbun, R. J., Ginting, B., Tarigan, P., \& Agusmidah, A. (2017). Lembaga Kerjasama (Lks) Bipartit Perusahaan dalam Penyelesaian Perselisihan Hubungan Industrial di Kabupaten Deli Serdang. USU Law Journal, 5(1).

PN, S. S. (2018). Karakteristik Penyelesaian Perselisihan Hubungan Industrial. Mimbar Yustitia, 2(1), $87-111$.

Santoso, S. (2019). Kekhususan Hukum Acara Pengadilan Hubungan Industrial. Jurnal Jatiswara, 34(1), 11-25.

Sudiarawan, K. A. (2017). Optimalisasi Fungsi Lembaga Kerjasama Bipartit Sebagai Forum Komunikasi dan Konsultasi antara Buruh dengan Pengusaha dalam Upaya Pencegahan Perselisihan Hubungan Industrial.

Zulkarnaen, A. H., \& Utami, T. K. (2016). Perlindungan Hukum terhadap Pekerja dalam Pelaksanaan Hubungan Industrial. PADJADJARAN Jurnal Ilmu Hukum (Journal of Law), 3(2), 407-427.

Undang-undang No. 2 Tahun 2004 Penyelesaian Perselisihan Hubungan Perindustrian.

Undang-undang No. 13 Tahun 2003 Ketenagakerjaan. 